\title{
PENGELOLAAN ARSIP DOKUMEN KEPENDUDUKAN PADA DINAS KEPENDUDUKAN DAN PENCATATAN SIPIL KOTA PARIAMAN
}

\author{
Marlinda \\ Peneliti Dinas Kependudukan dan Pencatatan Sipil, Kota Pariaman \\ linda_3545@yahoo.co.id
}

\begin{abstract}
Archives needed to be managed properly because archives have a very important role for the life of an institution/organization so that if there were someone who needed them, the archives could be provided quickly and accurately. The objectives of this research were to analyze the management of population document archives at the Department of Population and Civil Registration of Pariaman City in connection with the creation, arrangement, storage, and discovery of archives; to analyze the obstacles in managing the population document archives; and to formulate the solutions (efforts) that could be done in overcoming problems or obstacles encountered by the archive manager. This was a qualitative research. The finding of this study indicated that the current management of population document archives at Pariaman City was not optimal and has not been implemented properly so that the management system needed to be improved. It was necessary to establish a Standard Operating Procedure (SOP) in the field of archiving so that activities for archiving could be well controlled.
\end{abstract}

Keywords: Archives, Archives Management, Population Documents

\section{Pendahuluan}

Pemerintah Kota Pariaman telah menyelenggarakan administrasi kependudukan berdasarkan Peraturan Daerah nomor 4 tahun 2010 tentang Penyelenggaraan Administrasi Kependudukan (sesuai penjelasan Perda Pariaman Nomor 8 Tahun 2018). Dikutip dari Pasal 1 ayat 6 (Permendagri. Nomor 19 Tahun 2012 Tentang Pedoman Pendokumentasian Hasil Pendaftaran Penduduk Dan Pencatatan Sipil Di Daerah, 2012) menyebutkan bahwa Dinas Kependudukan dan Pencatatan Sipil merupakan perangkat pemerintah kabupaten/kota yang bertanggung jawab dan berwenang melaksanakan pelayanan dalam urusan administrasi kependudukan.

Dalam manajemen atau pengelolaan arsipnya, setiap instansi baik instansi swasta maupun pemerintahan pasti membutuhkan dan menginginkan administrasi yang baik. Oleh sebab itu, berbagai cara bisa dilakukan dalam pengelolaan arsip guna pengelolaan arsip yang baik bagi setiap instansi. Dalam rangka menciptakan arsip dokumen kependudukan perlu dilakukan pengelolaan arsip manual dan arsip 
elektronik sesuai dengan metode dan peraturan yang berlaku. Kenyataan ditemui di lapangan, arsip belum sepenuhnya tertata rapi karena masih banyak dokumen kependudukan yang sulit ditemukan ketika sewaktu-waktu dibutuhkan kembali oleh masyarakat karena dokumen mereka bermasalah dan harus diperbaiki kembali. Pengelola arsip akan kesulitan menemukan arsip dokumen yang mereka butuhkan dalam waktu yang singkat jika kearsipan suatu instansi/lembaga tersebut tidak tertata dengan rapi.

Mendukung keberhasilan organisasi, mudah dalam pencarian data, antisipasi dokumen hilang dan data lama bisa dicari serta ditemukan kembali apabila dibutuhkan, merupakan tujuan dari pengelolaan arsip. Dalam rangka pelaksanaan fungsi dan tugas organisasi, ketersediaan arsip sebagai bahan akuntabilitas kinerja dan sebagai alat bukti yang sah harus terjamin oleh pengelolaan arsip. Langkah yang bisa dilakukan yaitu denga mempelajari tata cara pengelolaan arsip dokumen kependudukan di Dinas Kependudukan dan Pencatatan Sipil Kota Pariaman. Oleh sebab itu, setiap organisasi politik, organisasi kemasyarakatan, pemerintahan daerah, lembaga negara, lembaga pendidikan, perseorangan dan perusahaan wajib membuktikan tanggungjawabnya dalam pelaksanaan, pengelolaan, penciptaan, dan pelaporan arsip yang tercipta dari kegiatan-kegiatannya.

Menurut Amsyah (dalam Rahmi et al., 2012) pengelolaan adalah terdiri atas proses penciptaan arsip, penyimpanan arsip, pemeliharaan arsip dan penemuan kembali arsip. Malabay (2014) mengemukakan manajemen kearsipan yaitu suatu proses perencanaan, pelatihan, pengawasan, pengembangan dan aktivitas manajerial yang ditujukan guna kegiatan penciptaan, penggunaan, pemeliharaan, dan penyusutan arsip supaya dapat dokumentasi yang baik yang sesuai dengan ketetapan/kebijakan yang nyata dan manajemen operasi organisasi yang efektif dan ekonomis.

Namun pada kenyataannya masih banyak instansi/lembaga yang kurang memperhatikan pengelolaan arsip baik arsip elektronik maupun arsip manual yang mana untuk bidang pelayanan admininistrasi kependudukan pada Disdukcapil Kota Pariaman, yang dihasilkan berupa arsip dokumen kependudukan (pendaftaran penduduk dan pencatatan sipil). Hal ini tentunya berdampak pada bertambahnya kapasitas arsip dokumen yang akhirnya menimbulkan berbagai kendala/ permasalahan, yang hubungannya tenaga pengelola, tempat penyimpanan, biaya pemeliharaan, saran, fasilitas ataupun faktor lain yang bisa menyebabkan kerusakan arsip.

Berdasarkan hasil studi dan wawancara penulis dilapangan pada bulan Oktober 2019 masih ditemukan beberapa kendala/permasalahan dalam pengelolaan arsip dokumen kependudukan pada Dinas Kependudukan dan Pencatatan Sipil Kota Pariaman, yaitu :

1. Kurangnya pemahaman pegawai terhadap perlunya arsip, menganggap tugastugas di bagian pengelolaan kearsipan tidak penting dan dipandang rendah.

2. Kurangnya petugas arsip, petugas arsip tidak sesuai bidang ilmunya, serta kurangnya pelatihan dan bimbingan mengenai kearsipan sehingga pengelolaan arsip terhambat. 
3. Membutuhkan waktu lama dalam pencarian/menemukan dokumen jika dibutuhkan. Karena kondisi gedung yang terbatas sehingga sering terjadi pemindahan ruangan arsip yang menyebabkan arsip tidak tertata seperti semula, malah semakin berantakan.

4. Keterbatasan biaya untuk pemeliharaan/pengadaan sarana dan fasilitas pengelolaan arsip seperti rak-rak, file kabinet, komputer dan scanner.

5. Peralatan/sarana/fasilitas pendukung dalam pengelolaan arsip kurang memadai.

6. Belum ada penyusutan atau pemusnahan arsip terhadap arsip lama yang sudah menumpuk dan dikarung, padahal umur arsip sudah lebih dari 5 tahun.

Pada penelitian ini penulis menitikberatkan pada pengelolaan arsip dokumen kependudukan, mulai dari penerimaan/penciptaan arsip, penataan arsip, penyimpanan arsip, pelayanan/penemuan kembali arsip. Adapun pengelolaan arsip dokumen kependudukan ini berada pada bagian pendokumentasian dokumen kependudukan yang melibatkan bagian pelayanan (pendaftaran pendudukan dan pencatatan sipil). Tujuan penelitian adalah (a) Mengetahui pengelolaan arsip dokumen kependudukan di Dinas Kependudukan dan Pencatatan Sipil Kota Pariaman sehubungan dengan penerimaan/penciptaan, penataan, penyimpanan, penemuan kembali arsip. (b) Mengetahui kendala-kendala yang ditemui dalam pengelolaan arsip dokumen kependudukan Dinas Kependudukan dan Pencatatan Sipil Kota Pariaman. (c) Mengetahui solusi/cara apa yang bisa dilakukan dalam mengatasi permasalahan atau kendala yang ditemui pengelola arsip. Dengan demikian, berdasarkan fenomena yang telah peneliti uraikan di atas, maka penulis tertarik untuk melakukan penelitian lebih lanjut tentang pengelolaan arsip dokumen kependudukan yang berjudul "Pengelolaan Arsip Dokumen Kependudukan pada Dinas Kependudukan dan Pencatatan Sipil Kota Pariaman”

\section{Tinjauan Kepustakaan}

\section{Arsip dan Dokumen Kependudukan}

Sedarmayanti (dalam Kalinda, 2019) mengemukakan kata arsip meliputi tiga pengertian, yaitu 1) Kumpulan naskah atau dokumen yang disimpan, 2) Gedung/ruang penyimpanan kumpulan naskah atau dokumen, 3) Organisasi atau lembaga yang mengelola dan menyimpan kumpulan naskah atau dokumen. Arsip menurut Sugiarto \& Teguh Wahyono (2015) secara harfiah istilah berasal dari bahasa Yunani yakni kata ache, lalu berubah sebagai archea, seterusnya mengalami perubahan kembali menjadi archeon. Archea artinya catatan atau dokumen mengenai permasalahan. Sedangkan Arsip menurut Pasal 1 ayat 2 (Anon 2009), yaitu rekaman kegiatan atau peristiwa dalam berbagai bentuk dan media sesuai dengan perkembangan teknologi informasi dan komunikasi yang dibuat dan diterima oleh lembaga negara, lembaga pemerintahan daerah, lembaga pendidikan, perusahaan, organisasi politik, organisasi kemasyarakatan, dan perseorangan dalam pelaksanaan kehidupan bermasyarakat, berbangsa dan bernegara.

Dari pendapat-pendapat para ahli di atas, penulis menyimpulkan pengertian arsip adalah kumpulan warkat/dokumen dalam berbagai bentuk, bernilai historis 
yang disimpan dan dipelihara guna ketika diperlukan warkat bisa dengan cepat dan mudah ditemukan kembali.

Selanjutnya pengelolaan arsip menurut Wursanto (dalam Mustika et al., 2018) yaitu kegiatan yang berhubungan dengan penerimaan warkat, pencatatan, penyimpanan, pengiriman, penyusutan atau pemusnahan warkat. Prosedur pengelolaan arsip yaitu: (1) Prosedur peminjaman/pengembalian arsip, (2) Prosedur Penyimpanan Arsip, (3) Prosedur penyusutan, (Ida Nuraida 2014). Pengertian pengelolaan menurut Soekanto (dalam Reza \& Andry, 2015:358) yaitu suatu proses yang dimulai dari proses perencanaan, pengaturan, pengawasan, penggerak sampai dengan proses terwujudnya tujuan.

Pengelolaan arsip bisa diartikan juga sebagai manejemen arsip, yaitu proses dari sebuah organisasi yang mengelola arsip baik arsip yang diciptakan maupun diterimanya dalam berbagai format dan media, (Anbarrini et al., 2016). Ririn Anbarrini menambahkan terdapat dua model dalam pengelolaan arsip: 1) Model Siklus Hidup (Life Cycle Model), kegunaannya mengelola arsip dan dokumen kertas secara manual. 2) Model Arsip Berkelanjutan (Record Continuum Model), yaitu biasa digunakan untuk mengelola arsip elektronik. Dari uraian di atas peneliti menyimpulkan bahwa dalam pengelolaan arsip yang dapat dijadikan indikator pengukur dari kegiatan-kegiatan tersebut adalah penciptaan arsip, penataan arsip, penggunaan arsip, pemeliharaan arsip, penemuan kembali arsip, dan penyusutan.

Selanjutnya, dokumen kependudukan menurut Peraturan Daerah Kota Pariaman Tahun 2018 Pasal 1 ayat 18 yaitu dokumen resmi yang diterbitkan oleh Disdukcapil yang mempunyai kekuatan hukum sebagai alat bukti autentik yang dihasilkan dari pelayanan Pencatatan Sipil dan Pendaftaran Penduduk. Kemudian dijelaskan pencatatan biodata penduduk, pencatatan atas pelaporan peristiwa kependudukan dan pendataan penduduk rentan administrasi kependudukan berupa kartu identitas atau surat keterangan kependudukan, seperti KIA, KTP, kartu keluarga, surat pindah/kedatangan disebut pendaftaran penduduk. Sedangkan pencatatan peristiwa penting yang dialami oleh seseorang dalam register pencatatan sipil pada instansi pelaksana teknis yang membidangi kependudukan dan pencatatan sipil seperti akta kematian, akta kelahiran, akta perceraian, akta perkawinan, akta pengesahan anak disebut pencatatan sipil.

Menurut Sedarmayanti (dalam Priansa \& Damayanti, 2015) tugas pokok unit kearsipan secara umum adalah: a) Mencatat warkat, b) Menerima warkat, c) Menyimpan, menata, menemukan kembali arsip dengan sistem tertentu, e) Memberikan pelayanan kepada pihak-pihak yang memerlukan arsip, d) Mendistribusikan warkat, f) Mengadakan perawatan/pemeliharaan arsip, dan g) Mengadakan atau merencanakan penyusutan dan sebagainya. Sedangkan menurut Choiriyah (dalam Priansa \& Damayanti, 2015) tugas pokok bagian kearsipan adalah mengatur arsip di lembaganya masing-masing dengan sebaik-baiknya, menyimpan dokumen sedemikian rupa supaya teratur dan mudah ditemukan kembali, memelihara atau merawat arsip dengan sebaik-baiknya, menyelamatkan arsip dari bahaya kemusnahan, serta meningkatkan mutu pelayanan dan mutu pelaksanaan kearsipan. 


\section{Faktor-Faktor yang Mempengaruhi Pengelolaan Arsip}

Pengelolaan arsip dipengaruhi oleh beberapa faktor, yaitu :

\section{a. Ruang Penyimpanan Arsip}

Keadaan ruangan penyimpanan dokumen/arsip agar selalu dalam keadaan kering dan bersih sehingga arsip dapat aman dari berbagai kerusakan. Ruangan penyimpanan hendaknya memiliki lokasi yang luas, supaya cukup untuk penyimpanan arsip. Sugiarto \& Teguh Wahyono (2015) mengemukakan bahwa untuk mendukung keawetan arsip, maka ruangan penyimpanan arsip mesti dibangun dan diatur sebaik mungkin. Sattar (2019) juga berpendapat, hal-hal yang harus diperhatikan untuk ruangan penyimpanan arsip adalah: tempat harus kering, kuat, terang dan berventilasi baik; pintu dan jendela gedung tidak menghadap langsung datangnya ke sinar matahari; suhu harus diatur berkisar antara $65^{\circ} \mathrm{F}-75^{\circ}$ $\mathrm{F}$ dan kelembapan udara sekitar $50^{\circ}-60^{\circ} \mathrm{F}$; AC dipasang selama 24 jam terus menerus.

\section{b. Fasilitas Pengelolaan Arsip}

Dalam suatu instasi, pengelolaan arsip yang baik mestinya didukung oleh fasilitas pengelolaan arsip tersebut, yakni perlengkapan dan peralatan penyimpanan arsip. Menurut Sugiarto \& Teguh Wahyono (2015) Peralatan yang dipergunakan bagi penyimpanan arsip yang berjumlah banyak dapat dikelompokkan dalam 3 (tiga) bentuk alat penyimpanan, yaitu: 1) Vertical file (alat penyimpanan tegak vertikal), 2) Power file (alat penyimpanan berat), 3) Lateral file (alat penyimpanan menyamping). Selain peralatan penyimpanan yang harus disiapkan juga harus menyiapkan perlengkapan-perlengkapan dalam penyimpanan dokumen/arsip. Berdasarkan pendapat di atas dapat dipahami bahwa peralatan dan perlengkapan arsip mempunyai kegunaan untuk memudahkan penyimpanan dan penemuan kembali arsip, serta dapat meminimalisir terjadinya kerusakan atau kehilangan pada arsip.

\section{c. Petugas Arsip}

Petugas yang mengurus segala sesuatu tentang arsip disebut petugas arsip. Dalam suatu lembaga/organisasi, petugas arsip disebut juga sebagai arsiparis. The Liang Gie (dalam Sugiarto \& Teguh Wahyono, 2005) mengemukakan bahwa untuk dapat menjadi petugas kearsipan yang baik diperlukan sekurang-kurangnya empat syarat yaitu: 1) Ketelitian, petugas arsip harus cermat dan mempunyai mata yang sempurna sehingga pegawai itu dapat membedakan nama-nama, perkataanperkataan atau angka-angka yang sepintas lalu tampaknya sama; 2) Kecerdasan, petugas arsip itu tidak harus mempunyai pendidikan yang tinggi, tetapi sekurangkurangnya pegawai arsip harus dapat menggunakan pikirannya dengan baik, karena ia harus dapat memilih kata-kata untuk sesuatu pokok hal; 3) Kecekatan, pegawai arsip harus mempunyai kondisi jasmani yang baik sehingga ia dapat bekerja secara gesit; 4) Kerapian, supaya kartu-kartu, dokumen-dokumen dan tumpukan arsip tersusun rapi maka kerapian sangat diperlukan.

Seorang petugas kearsipan tidak harus memiliki tingkat kecerdasan yang sangat tinggi, cukup dengan memiliki tingkat kecerdasan yang baik serta beberapa 
syarat umum terpenuhi. Sugiarto \& Teguh Wahyono (2015) mengungkapkan bahwa syarat umum yang harus dimiliki oleh seorang petugas kearsipan adalah memiliki ketelitian dan kerapian, dapat menyimpan rahasia, tekun, dan disiplin.

Berdasarkan uraian beberapa pendapat para ahli dapat disimpulkan bahwa petugas arsip atau arsiparis harus mempunyai kecakapan dan keterampilan dibidang pengelolaan arsip, kerapian dan ketelitian, disiplin, tekun, dan dapat menyimpan rahasia serta mempunyai latar belakang pendidikan kearsipan. Setidaknya ia telah menempuh pelatihan tentang kearsipan sehingga dapat mengelola arsip dengan handal.

\section{Metode Penelitian}

Penelitian ini menggunakan pendekatan kualitatif. Penelitian ini dilaksanakan di Dinas Kependudukan dan Pencatatan Sipil Kota Pariaman, beralamat di Jalan Syekh Burhanuddin Nomor 145 Karan Aur. Informan penelitian yang dipilih yaitu pegawai-pegawai juru kunci atau orang-orang yang memiliki informasi mendalam tentang tema yang diteliti. Untuk data primer peneliti dapat langsung dari informan yang mengetahui seluk beluk informasi yang diteliti, yaitu Kabid Pelayanan Administrasi Kependudukan selaku kepala yang membidangi Sub Bagian Pelayanan dan Sub Bagian Pendokumentasian Dokumen Kependudukan, selanjutnya Kasi Pendokumentasian Kependudukan yang bertanggungjawab penuh atas pengelolaan arsip, Staf Pengelolaan Arsip sebanyak 2 orang, Staf Pelayanan dan Masyarakat berjumlah 10 orang. Sementara data sekunder yang digunakan adalah literatur yang relevan, seperti buku-buku referensi, laporan penelitian dan artikel-artikel melalui jurnal.

Pengumpulan data dalam penelitian ini dilakukan melalui wawancara. Sedangkan untuk menggali data penelitian yang lebih lengkap dari informan, peneliti sengaja memilih informan yang bisa mewakili dalam menjawab sehubungan informasi yang dibutuhkan. Selain itu data juga peneliti dapatkan melalui observasi. Observasi yang dimaksud yaitu untuk mengetahui bagaimana pengelolaan arsip pada Disdukcapil Kota Pariaman. Kemudian juga data penelitian ini dikumpulkan melalui studi dokumentasi. Analisis data dalam penelitian ini dilakukan dengan model analisis interaktif dengan tahap: 1) Reduksi data, 2) Penyajian data, dan 3) Penarikan kesimpulan/verifikasi, berisi uraian keseluruhan.

\section{Hasil dan Pembahasan}

\section{Pengelolaan Arsip di Disdukcapil Kota Pariaman}

Bagian pengelolaan kearsipan pada Dinas Kependudukan dan Pencatatan Sipil Kota

Pariaman merupakan bagian dari bidang pendokumentasian dokumen kependudukan yang langsung berada di bawah bidang Administrasi Kependudukan, dan menjalankan tugas pokok kearsipan dokumen kependudukan sesuai dengan Permendagri/Peraturan Menteri Dalam Negeri Nomor 19 Tahun 
2012. Dalam pengelolaan arsip, Disdukcapil sudah memakai kode klasifikasi dalam pengarsipannya namun belum maksimal karena kurang didukung oleh sarana dan prasarana. Misalkan arsip yang sudah diolah harusnya disimpan di rak-rak yang tersedia dan rak tersebut harus diberi kode sesuai dengan kode klasifikasi yang ada, yang tujuannya memudahkan petugas arsip dalam menemukan kembali arsip. Namun kenyataannya arsip tersebut tidak bisa disimpan karena kurangnya rak-rak arsip dan keterbatasan gedung tidak memungkinkan menambah rak.

Kegiatan pengelolaan arsip pada Disdukcapil Kota Pariaman, yaitu mulai dari proses penerimaan arsip, penataan arsip, penyimpanan arsip dan penemuan kembali. Alur pengelolaan arsip di Disdukcapil tersebut dapat digambarkan sebagai berikut.

\section{Bagan Alur Pengelolaan Arsip Dokumen Kependudukan}

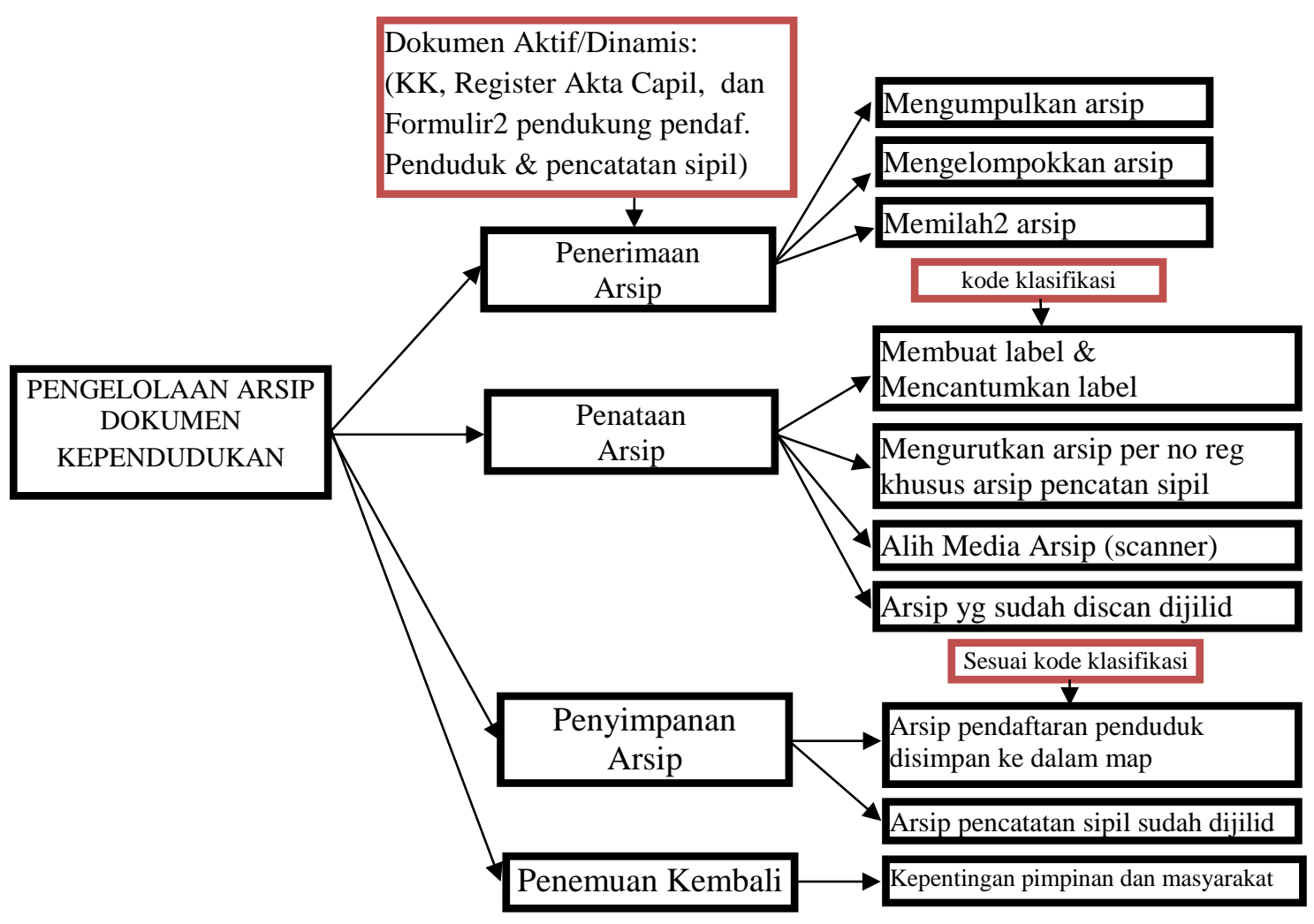

\section{Kendala Pengelolaan Arsip di Disdukcapil Kota Pariaman}

Menurut pengamatan dan hasil wawancara penulis, banyak kendala dan permasalahan yang ditemui sehubungan dengan pengelolaan arsip dokumen kependudukan. Adapun kendala dalam pengelolaan arsip dokumen kependudukan yang dihadapi oleh Dinas Kependudukan dan Pencatatan Sipil Kota Pariaman, antara lain: 
1. Kurangnya pemahaman pegawai terhadap perlunya arsip, menganggap tugastugas di bagian pengelolaan kearsipan tidak penting dan dipandang rendah. Selain itu, peningkatan volume arsip tiap tahun harusnya diiringi dengan penambahan pegawai/petugas arsip; namun kenyataannya pegawai malah dikurangi. Kondisi ini juga disebabkan banyak pegawai yang menolak ditempatkan di bagian kearsipan.

2. Kurangnya petugas arsip, petugas arsip tidak sesuai bidang ilmunya, serta kurangnya pelatihan dan bimbingan mengenai kearsipan sehingga pengelolaan arsip terhambat. Faktor penghambat lainnya adalah keterbatasan SDM pada Disdukcapil Kota Pariaman yang menyebabkan beberapa pegawai mempunyai tugas tambah diperbantukan pada bidang lain selain tupoksi mereka sendiri sehingga menyebabkan pengelolaan arsip tidak fokus dan tidak terlaksana dengan baik. Selain itu, meskipun pendidikan petugas arsip sudah relatif baik namun petugas arsip tersebut belum mempunyai skill di bidang kearsipan.

3. Pencarian/penemuan dokumen seringkali membutuhkan waktu lama jika dibutuhkan. Karena kondisi gedung yang terbatas sehingga sering terjadi pemindahan ruangan arsip yang menyebabkan arsip tidak tertata seperti semula, malah semakin berantakan.

4. Keterbatasan biaya untuk pemeliharaan/pengadaan sarana dan fasilitas pengelolaan arsip seperti rak-rak, file kabinet, komputer dan scanner.

Tabel 1 Jumlah peralatan arsip tiap tahun

\begin{tabular}{clcccc}
\hline No & Peralatan/Sarana & $\mathbf{2 0 1 6}$ & $\mathbf{2 0 1 7}$ & $\mathbf{2 0 1 8}$ & $\mathbf{2 0 1 9}$ \\
\hline 1 & Lemari Arsip & 2 & 2 & 2 & 2 \\
2 & Rak-rak arsip & 8 & 8 & 8 & 8 \\
3 & File kabinet & 1 & 1 & 1 & 1 \\
4 & Meja Kerja & 2 & 2 & 2 & 2 \\
5 & Komputer & 2 & 2 & 2 & 2 \\
6 & Scanner & 2 & 2 & 1 & 1 \\
\hline
\end{tabular}

Sumber: Data Olahan Penulis Tahun 2020

Seperti yang terlihat pada Tabel 1 jumlah peralatan/fasilitas masih sama tiap tahunnya tidak ada penambahan. Karena anggaran yang kecil belum memungkinkan untuk pengadaan peralatan yang baru.

5. Peralatan/sarana/fasilitas pendukung dalam pengelolaan arsip kurang memadai. Kurangnya rak-rak arsip dan file kabinet, ruangan arsip yang sempit tidak memungkinkan untuk menambah rak-rak arsip. Di sisi lain bertambahnya kapasitas arsip yang berkesinambungan dari bagian pelayanan menjadikan arsip menumpuk, 
sedangkan rak-rak yang ada tidak dapat memuat arsip lagi sehingga arsip yang ada harus dimasukkan ke karung.

Tabel 2 Peralatan/sarana yang ada pada bagian pengelolaan arsip

\begin{tabular}{clcc}
\hline No & Peralatan/Sarana & Jumlah & Keadaan \\
\hline 1 & Lemari Arsip & 2 & kurang baik \\
2 & Rak-rak arsip & 8 & 6 baik, 2 kurang \\
3 & File kabinet & 1 & Kurang baik \\
4 & Meja Kerja & 2 & baik \\
5 & Komputer & 2 & baik \\
6 & Scanner & 1 & baik \\
\hline
\end{tabular}

Sumber : Data Olahan Penulis Tahun 2020

Tabel 3 Arsip yang tercipta per tahun pada bagian pengelolaan arsip

\begin{tabular}{clcccc}
\hline No & Dokumen Kependudukan & $\mathbf{2 0 1 6}$ & $\mathbf{2 0 1 7}$ & $\mathbf{2 0 1 8}$ & $\mathbf{2 0 1 9}$ \\
\hline 1 & Kartu Keluarga & 5.393 & 4.465 & 3.238 & 5.228 \\
2 & Surat Pindah/Datang & 1.765 & 1.697 & 1.732 & 1.987 \\
3 & Akta Kelahiran & 4.328 & 1.977 & 2.360 & 4.975 \\
4 & Akta Kematian & 314 & 254 & 278 & 367 \\
5 & Akta Perkawinan & 6 & 6 & 2 & 1 \\
\hline & Total Jumlah Per Tahun & $\mathbf{1 1 . 8 0 6}$ & $\mathbf{8 . 3 9 9}$ & $\mathbf{7 . 6 1 0}$ & $\mathbf{1 2 . 5 5 8}$ \\
\hline
\end{tabular}

Sumber : Data Olahan Penulis Tahun 2020

Dari Tabel 2 dan Tabel 3 di atas dapat kita lihat bahwa bagian pengelolaan arsip sudah memiliki 8 rak arsip, namun 2 rak kondisinya kurang baik, kemudian karena kondisi ruangan yang sempit dan terbatas 2 buah lemari arsip masingmasing terletak di gudang dan koridor. Kemudian dengan diberlakukannya perda yang baru tentang dihapusnya denda bagi yang terlambat dalam pengurusan dokumen kependudukan (Desember tahun 2018), pada tabel 5 dapat kita lihat terjadi lonjakan jumlah arsip dokumen kependudukan pada tahun 2019. Sehingga banyaknya volume arsip yang masuk pada bagian pengelolaan arsip tidak sebanding dengan jumlah rak yang ada. 
6. Arsip tidak terjamin keamanannya karena tidak ada ruangan khusus arsip, masih bergabung dengan bidang lain. Seringkali pegawai lain dengan leluasa mencari dan mengambil arsip/dokumen yang mereka butuhkan tanpa melalui prosedur dan bahkan tanpa sepengetahuan petugas arsip (ketika petugas arsip tidak ditempat), sehingga arsip ada yang hilang atau susah ditemukan karena ada diantara mereka yang meminjam tidak mengembalikan dan menaruh pada tempatnya.

7. Belum ada penyusutan atau pemusnahan arsip terhadap arsip lama yang sudah menumpuk dan dikarung, padahal umur arsip sudah lebih dari 5 tahun.

Dari uraian kendala dan permasalahan tersebut menunjukkan bahwa pengelolaan arsip dokumen kependudukan pada Disdukcapil Kota Pariaman belum optimal dan belum terlaksana dengan baik.

\section{Upaya Mengatasi Kendala Pengelolaan Arsip di Disdukcapil Kota Pariaman}

Untuk mengatasi kendala dan permasalahan yang dihadapi bagian pengelolaan arsip, ada beberapa cara yang harus dilakukan, antara lain dapat kita lihat pada bagan di bawah ini :

\section{Bagan upaya untuk mengatasi kendala dan permasalahan}

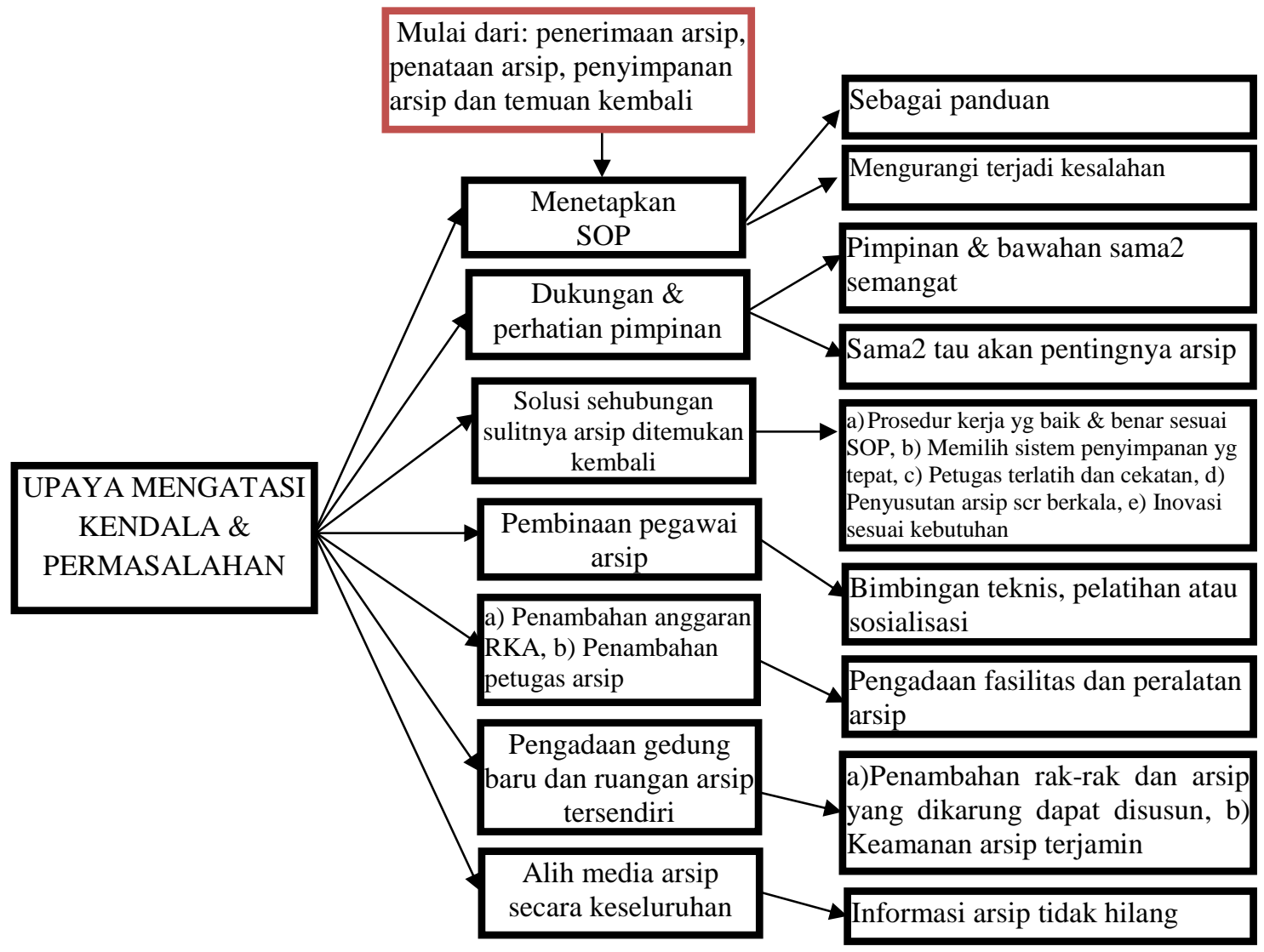


Dari bagan diatas dapat kita lihat upaya untuk mengatasi kendala dan permasalahan yang dihadapi bagian pengelolaan arsip, yaitu :

1. Pertama sekali penting adanya/ditetapkan Standar Operating Procedure (SOP) pada bidang kearsipan, tujuan utamanya adalah memberikan panduan atau pedoman kerja agar kegiatan yang ada pada bidang kearsipan dapat terkontrol sesuai dengan aturan yang sudah ditetapkan sehingga dapat mengurangi terjadinya kesalahan dalam melakukan proses kerja. Hasil penelitian ini memperkuat teori-teori yang telah dijelaskan pada kajian teori yang dikemukakan oleh Purnamasari (dalam Daini \& Marlini, 2017) bahwa tujuan dan fungsi SOP diantaranya; a) Mengetahui dengan jelas peran dan fungsi tiaptiap posisi dalam organisasi, b) Membentuk kedisiplinan kepada semua anggota organisasi baik dalam institusi, organisasi maupun perusahaan, c) Menjaga tingkat kinerja yang konsisten pada masing-masing unit kerjanya, d) Memperlancar pekerjaan atau tugas karyawan, e) Untuk meminimalkan kesalahan/kegagalan, keraguan, duplikasi inefisiensi, f) Memberikan kemudahan dalam melaksanakan pekerjaan sehingga semua karyawan menyadari akan tanggungjawab pekerjaan, memahami dan mengetahui hak dan kewajibannya.

2. Dukungan dan perhatian dari pimpinan sangat penting dalam pengelolaan arsip serta memberikan pemahaman tentang esensial arsip kepada bawahannya sehingga baik pimpinan atau pegawai semangat dengan rencana perbaikan dan penyempurnaan bagian kearsipan. Secara teori penelitian ini mendukung pendapat ahli Handoko (dalam Abriani et al., 2018) yang menyatakan bahwa seorang pemimpin dapat mempengaruhi moral, kepuasan kerja, keamanan, kualitas kehidupan kerja dan tingkat prestasi suatu organisasi dan juga berperan dalam membentuk kelompok, organisasi atau masyarakat untuk mencapai tujuan. Juga didukung hasil penelitiannya yang menjelaskan bahwa dukungan dan perhatian pimpinan di kantor desa sangat positif terhadap tata kelola arsip.

3. Solusi sehubungan dengan sulitnya ditemukan kembali arsip dengan cepat dan tepat adalah; (a) menggunakan prosedur kerja yang baik dan benar sesuai SOP yang telah ditetapkan, (b) memilih sistem penyimpanan yang tepat, (c) petugas arsip yang terlatih dan cekatan, (d) melakukan penyusutan arsip secara berkala, (e) mengadakan inovasi-inovasi sesuai kebutuhan. Tersedianya ruangan penyimpanan yang memadai termasuk salah satu faktor pendukung terlaksananya pengelolaan arsip yang baik oleh sebuah lembaga/organisasi. Sebagaimana dalam penjelasan lampiran Permendagri No. 19 Tahun 2012: hal 27, dapat disimpulkan bahwa penyimpanan ruangan pengelolan arsip dokumen kependudukan harus: (1) Jauhkan dari pencahayaan matahari langsung, (2) Ruangan kerja pegawai harus tersendiri atau terpisah, (3) Cukup lampu penerangan, (4) Dipasang teralis besi pada rangka jendela, (5) Aman dan bersih dari serangga dan binatang lain, (6) Rancangan lantai bangunan dan ruangan mesti bisa menahan beban berat rak dan beban arsip yang akan tersimpan, (7) Hindari daerah/lokasi yang mempunyai kandungan polusi tinggi bila hendak membangun gedung penyimpanan arsip seperti bekas perkebunan atau hutan, rawan banjir, rawan kebakaran serta pabrik/keramaian. Teori ini diperkuat oleh pendapat dari Wijaya et al. (2018) hasil penelitiannya mengemukakan bahwa 
arsip-arsip disimpan di tempat yang tidak lembab serta dibersihkan, kemudian mengatasi pemusnahan atau penyusutan mengamati jadwal retensi arsip. Senada dengan hasil penelitian Sari et al. (2019) yang mengemukakan faktorfaktor yang mempengaruhi pengelolaan arsip yaitu a) Sistem penyimpanan arsip b) Fasilitas yang digunakan c) Petugas kearsipan.

4. Pegawai pengelolaan arsip perlu mendapat pembinaan, seperti mengikuti bimbingan teknis, pelatihan atau sosialisasi guna menambah keahlian/ keterampilan pegawai kearsipan tersebut. Kondisi ini senada dengan pendapat Atmaja dan Oktarina (dalam Wati \& Oktarina, 2019), dalam penelitianya menyebutkan bahwa terdapat pengaruh yang positif dan signifikan secara parsial antara kompentensi petugas kearsipan terhadap kelancaran pengelolaan kearsipan di Dinas Perpustakaan dan Kearsipan Daerah Kabupaten Batang. Dengan petugas arsip yang cermat dan rajin, meskipun arsip bertambah banyak namun dapat dikelola dengan baik dan tidak menyebabkan penumpukan dan kehilangan arsip. Sumber Daya Manusia (SDM) yang kompeten dan profesianal, sarana prasarana serta fasilitas pendukung lainnya yang dipergunakan dalam membantu pengelolaan arsip, dan dana yang tersedia untuk pemeliharaan arsip tersebut berpengaruh pada efektifitas pengelolaan arsip pada suatu unit kerja/organisasi.

5. Untuk kelancaran kerja bagian pengelolaan arsip perlu adanya: a) Pengadaan dan penambahan fasilitas/peralatan kerja. Oleh karena itu penambahanan anggaran pada RKA perubahan perlu diusulkan guna pemeliharaan/pengadaan fasilitas pengelolaan arsip dengan memperhatikan anggaran belanja yang jelas supaya pelaksanaan pengelolaan arsip bisa dilakukan dengan sebaik-baiknya. b) Penambahan petugas arsip/SDM. Secara teori hasil penelitian ini senada dengan hasil penelitian Nining Abriani yang mengemukakan bahwa faktorfaktor yang sangat menentukan bagi keberhasilan tata kelola arsip pada kantor desa di wilayah Kecamatan Sumbang adalah dukungan perhatian pimpinan dan anggaran, karena tanpa adanya dukungan perhatian dari pimpinan dan anggaran maka kegiatan pengelolaan arsip tidak dapat berjalan dengan optimal, kebutuhan sarana prasarana tidak akan terpenuhi. Hasil penelitian ini juga memperkuat pendapat/teori ahli A. W Widjaya (dalam Madaling \& Harun, 2019), yang mengemukakan bahwa secara umum ada 3 faktor yang menentukan keberhasilan pengelolaan arsip, yaitu: (1) sistem penyimpanan arsip, (2) Fasilitas kearsipan yang memenuhi syarat, (3) Petugas kearsipan, (4) Lingkungan kerja kearsipan. Namun hal ini berbeda dengan pendapat ahli Suhana yang mengemukakan bahwa keberadaan ruangan penyimpanan arsip juga tidak terjamin ditemukannya kembali arsip secara cepat dan tepat apabila tidak adanya SDM yang kompetensi dan profesional dibidang kearsipan dalam melakukan kegiatan pengelolaan arsip (Suhana 2016).

6. Sehubungan dengan rak-rak arsip dan file kabinet yang kurang, dengan ruangan arsip yang sempit, maka pimpinan perlu merencanakan usulan pengadaan gedung arsip tersendiri/ruang tersendiri, sehingga bisa diusulkan pula pengadaaan rak-rak baru/file kabinet yang tujuannya arsip yang dikarung/bertumpuk bisa disusun dalam rak-rak arsip yang baru. Kondisi ini senada dengan pernyataan yang terkandung dalam Lampiran Permendagri 
Nomor 19 Tahun 2012 Tentang Pedoman Pendokumentasian Hasil Pendaftaran Penduduk Dan Pencatatan Sipil di Daerah, yang menyatakan bahwa ruangan penyimpanan arsip tersendiri/terpisah dari ruangan kerja pegawai.

Untuk mengurangi resiko kerusakan arsip secara fisik perlu dilakukan alih media arsip secara keseluruhan, tidak hanya arsip akta kelahiran, akta kematian, akta perkawinan (pencatatan sipil) tetapi juga arsip kartu keluarga, surat kedatangan/pindah (pendaftaran penduduk) agar informasi arsip tidak hilang. Secara teori penelitian ini mendukung pendapat Tiara \& Husna (2018) yang menyatakan bahwa alih media merupakan salah satu kegiatan pelestarian dengan mengalihkan media arsip ke dalam bentuk lain. Hal tersebut bertujuan untuk menyelamatkan arsip baik dari sei fisik maupun informasinya agar dapat dimanfaatkan. Teori ini diperkuat oleh hasil penelitian (Narendra 2016) yang menjelaskan bahwa proses kegiatan, sarana, spesifikasi, alataplikasi kegiatan tramsformasi media tersebut dan proses penyimpanan dokumen hasil kegiatan alih media digital agar tetap lestari nilai informasinya.

\section{Penutup}

Berdasarkan pembahasan di atas maka dapat disimpulkan bahwa kegiatan pengelolaan arsip pada Disdukcapil Kota Pariaman, yaitu mulai dari proses penerimaan arsip, penataan arsip, penyimpanan arsip dan penemuan kembali arsip. Proses pengelolaan arsip dokumen kependudukan pada Dinas Kependudukan dan Pencatatan Sipil belum sesuai dengan teori-teori yang ada. Sehingga pengelolaan arsip dokumen kependudukan pada Dinas Kependudukan dan Pencatatan Sipil Kota Pariaman belum optimal dan belum terlaksana dengan baik. Selain itu faktor penunjang/yang mempengaruhi pengelolaan arsip belum memenuhi dan belum memadai sehingga banyak ditemui kendala-kendala/permasalahan dalam pengelolaan arsip dokumen kependudukan. Dengan adanya upaya/solusi yang diusulkan dan didukung oleh teori-teori yang ada diharapkan pengelolaan arsip dokumen kependudukan pada Dinas Kependudukan dan Pencatatan Sipil dapat terlaksana dengan baik dan optimal. Karena arsip memiliki peranan yang begitu penting bagi kehidupan organisasi/lembaga, upaya/solusi yang ada diharapkan arsip dapat dikelola dengan baik sehingga apabila sewaktu-waktu arsip dibutuhkan oleh pihak yang membutuhkan maka arsip bisa diberikan dengan cepat dan tepat.

Sehubungan kesimpulan di atas, saran penulis yang mungkin bisa dipertimbangkan, yaitu untuk memaksimalkan pengelolaan kearsipan dokumen kependudukan pada Disdukcapil, maka pegawai arsip hendaknya fokus terhadap tupoksinya, tidak diperbantukan pada bidang lain. Kemudian agar Kepala Disdukcapi serius menangani masalah arsip yang sudah menumpuk, yaitu dengan melakukan penyusutan arsip dokumen kependudukan yang umurnya lebih dari 5 tahun sehingga tidak terjadi penumpukan arsip di karung, untuk mempercepat proses penyusutan arsip maka Kepala Disdukcapil sesegera mungkin mengusulkan 
membentuk tim penyusunan JRA yang melibatkan Kepala Daerah dan pejabat lain yang terkait.

\section{DAFTAR KEPUSTAKAAN}

Abriani, Nining, Anis Anggorowati, and Nugraheni Panca Wardani. 2018. "Tata Kelola Arsip Kantor Desa Di Wilayah Kecamatan Sumbang Kabupaten Banyumas Dalam Mewujudkan Tertib Arsip Desa." Khazanah: Jurnal Pengembangan Kearsipan 11(1):26. doi: 10.22146/khazanah.41536.

Anbarrini, Ririn, Rudi Susilana, and Hana Silvana. 2016. "Pengelolaan Arsip Pada Badan Perpustakaan Dan Kearsipan Daerah Provinsi Jawa Barat." Administrasi 3(1):59-73.

Anon. 2009. "Undang-Undang Republik Indonesia Nomor 43 Tahun 2009 Tentang Kearsipan."

Anon. 2012. "Permendagri. Nomor 19 Tahun 2012 Tentang Pedoman Pendokumentasian Hasil Pendaftaran Penduduk Dan Pencatatan Sipil Di Daerah.” Pp. 1036-37 in.

Anon. n.d. "Lampiran Permendagri Nomor 19 Tahun 2012 Tentang Pedoman Pendokumentasian Hasil Pendaftaran Penduduk Dan Pencatatan Sipil Di Daerah."

Daini, Helmi, and Marlini. 2017. "Pembuatan Standard Operating Procedure (SOP) Pengelolaan Arsip Dinas Kearsipan Dan Perpustakaan Provinsi Sumatera Barat." Jurnal Ilmu Informasi Perpustakaan Dan Kearsipan $5(1): 238-46$.

Ida Nuraida. 2014. Manajemen Administras Perkantoran. Yogyakarta: PT. Kanisius.

Kalinda, Linda. 2019. "Pengelolaan Arsip Berbasis Digital Oleh Pegawai Di Kantor Pengadilan Agama Ciamis.” Dinamika 6(3):76-86.

Madaling, and Hamlia Harun. 2019. "Sistem Pengelolaan Arsip Perkara Perdata Pada Kepaniteraan Pengadilan Negeri Sidereng Rappang." MODERAT 5(1):121-30.

Malabay. 2014. "Kajian Analisis Dan Perancangan Model Manajemen Arsip Dalam Rangka Tertib Administrasi Kearsipan (Studi Kasus : Fakultas Ilmu Komputer)." Ilmu Komputer 10(2, September):72-79.

Mustika, Reni, Aprillian Chairunesa, Desti Dwi Putri, and Eksi Pratama. 2018. “Pengelolaan Arsip Di Detik Sumatera Selatan." Jurnal Iqra' 12(01):83-98.

Narendra, Albertus Pramukti. 2016. "Model Transformasi Media Melalui Digitalisasi (Studi Kasus Alih Media Kartografi Di Badan Arsip Dan Perpustakaan Provinsi Jawa Tengah).” 2(2):212-24.

Priansa, and Damayanti. 2015. Administrasi Dan Operasional Perkantoran. 
Bandung: Alfabeta, CV.

Rahmi, Hayatur, Sukaesih, and Nurmaya Prahatmaja. 2012. "Pengelolaan Arsip Dinamis Aktif Di Badan Kepegawaian Daerah Provinsi Jawa Barat." Mahasiswa Universitas Padjadjaran 1(1):1-10.

Reza, Widia, and Hendry Andry. 2015. "Pelaksanaan Pengelolaan Arsip Pada Bagian Seksi Pelayanan Lelang Di Kantor Pelayanan Kekayaan Negara Dan Lelang Pekanbaru." Valuta 1(2):353-67.

Sari, Tri Rama, Sarwita Pebriani, Anggun Latifah, Adi Setiawan, and Amy Triyani. 2019. "Manajemen Pengelolaan Arsip Dinamis Di Balai Penelitian Dan Pengembangan Lingkungan Hidup Kota Palembang." Iqra' 13(2):95115.

Sattar. 2019. Manejemen Kearsipan. Yogyakarta: Deepublish.

Sugiarto, Agus, and Teguh Wahyono. 2005. Manajemen Kearsipan Modern, Dari Konvensional Ke Basis Komputer. Yogyakarta: Gava Media.

Sugiarto, Agus, and Teguh Wahyono. 2015. Manajemen Kearsipan Elektronik. Yogyakarta: Gava Media.

Suhana. 2016. "Pengaruh Sumber Daya Manusia Dan Ruangan Penyimpanan Arsip Dalam Melakukan Kegiatan Pengelolaan Kearsipan Di Pusat Reaktor Serba Guna.” Buletin Pengelolaan Reaktor Nuklir 13(1).

Tiara, Farrah Mudhia, and Jazimatul Husna. 2018. "Analisis Alih Media Arsip Aktif Personal File Untuk Temu Kembali Arsip Di Pt Sucofindo Cabang Semarang." Jurnal Ilmu Perpustakaan 7(4):141-50.

Wati, Rizqi Mustika, and Nina Oktarina. 2019. "Pengelolaan Arsip Dinamis Akta (Studi Kasus Di Dinas Kependudukan Dan Pencatatan Sipil Kabupaten Semarang).” Economic Education Analysis Journal 8(3):925-35. doi: 10.15294/eeaj.v8i3.35009.

Wijaya, Recki Ari, Bambang Budi Wiyono, and Ibrahim Bafada. 2018. "Pengelolaan Kearsipan." Jurnal Administrasi Dan Manajemen Pendidikan $1(2): 231-37$. 